Santa Clara Law

Santa Clara Law Digital Commons

\title{
The International Citizens' Tribunal for Sudan Case Number: ICTS-1 the Prosecutor Against Omar Hasan Ahmad Al-Bashir President of the Government of Sudan
}

Beth Van Schaack

Santa Clara University School of Law, bvanschaack@scu.edu

Follow this and additional works at: http://digitalcommons.law.scu.edu/facpubs

\section{Automated Citation}

Beth Van Schaack, The International Citizens' Tribunal for Sudan Case Number: ICTS-1 the Prosecutor Against Omar Hasan Ahmad AlBashir President of the Government of Sudan (2008),

Available at: http://digitalcommons.law.scu.edu/facpubs/182 


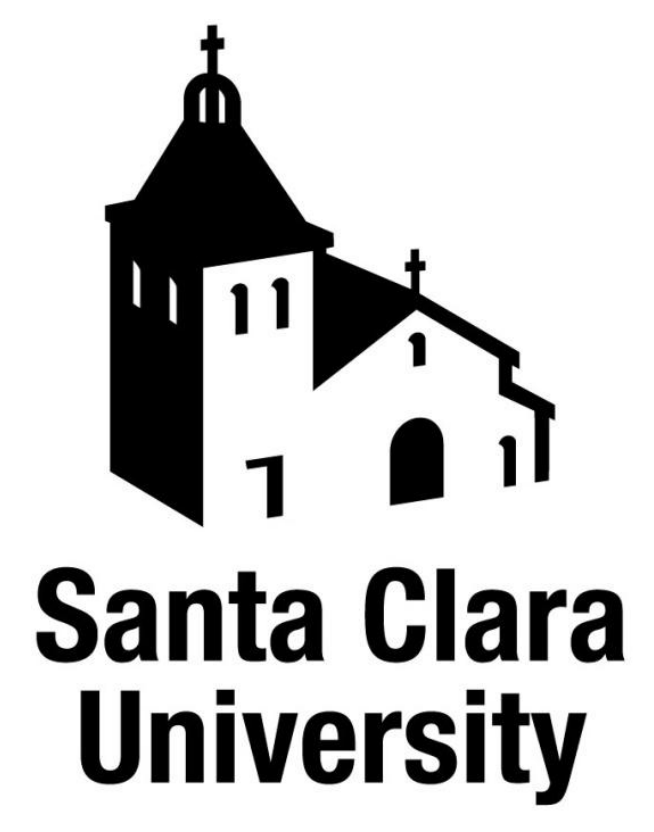

Santa Clara University School of Law

Legal Studies Research Papers Series

Working Paper No. 08-58, July 2008

THE INTERNATIONAL CITIZENS' TRIBUNAL FOR SUDAN CASE NUMBER:

ICTS-1 THE PROSECUTOR AGAINST OMAR HASAN AHMAD AL-BASHIR PRESIDENT OF THE GOVERNMENT OF SUDAN

\author{
Beth Van Schaack \\ Professor of Law \\ Santa Clara University School of Law
}

This paper can be downloaded without charge from the Social Science Research Electronic Paper Collection:

http://ssrn.com/abstract $=1160448$ 


\title{
THE INTERNATIONAL CITIZENS' TRIBUNAL FOR SUDAN
}

\author{
CASE NUMBER: ICTS-1
}

THE PROSECUTOR

\author{
AGAINST \\ OMAR HASAN AHMAD AL-BASHIR \\ PRESIDENT OF THE GOVERNMENT OF SUDAN
}

INDICTMENT

This indictment concerns a military regime that is criminal to its core. Since its violent assumption of power in 1989, the Government of Sudan has intentionally launched, orchestrated, and knowingly enabled a consistent pattern of gross human rights abuses against segments of the Sudanese civilian population. As detailed more fully in this Indictment, these abuses include widespread and systematic murders; deportations and forcible transfers of entire communities; enslavement; torture; rape; persecution; the destruction of civilian property without military necessity; pillage; and the deliberate infliction of adverse conditions of life. This pattern and practice of abuses rises to the level of crimes against humanity, genocide, and war crimes under international criminal law. At all times relevant to this Indictment, civilians have been the intentional and primary object of these attacks. In particular, these abuses have targeted a number of minority tribal groups expressing opposition to, or perceived to be in opposition of, the Government of Sudan and its hegemonic control over the country, including the Fur, Massaleit, Zaghawa, Tunjur, and Dajo people of Darfur; the peoples of the Nuba Mountains; the Dinka people; the Nuer people; the people of the Shilluk Kingdom; and the Beja people of East Sudan.

The defendant OMAR HASAN AHMAD AL-BASHIR sits at the apex of this repressive military dictatorship. AL-BASHIR exercises effective authority, command, and control over all regular and irregular armed and police forces within the Government of Sudan. In addition, ALBASHIR's government has deployed, supported, aided and abetted a number of militia and paramilitary groups, including the so-called janjaweed and murahaleen in Darfur and elsewhere as agents of the Government of Sudan to advance the Government's repressive and genocidal aims while at the same time enabling deniability on the part of the Government.

In light of these facts, as set forth in greater detail below, the Prosecutor of the International Citizens' Tribunal for Sudan hereby charges:

\section{OMAR HASAN AHMAD AL-BASHIR}

With CRIMES AGAINST HUMANITY, GENOCIDE, and VIOLATIONS OF THE LAWS AND CUSTOMS OF WAR as set forth below. These abuses are in contravention of the Statute of this Tribunal, which closely mirrors that of the International Criminal Court; customary international criminal law; and international treaties to which Sudan is a State Party or is bound by customary international law. These treaties include: 
- The Convention on the Prevention and Punishment of the Crime of Genocide;

- The Slavery Convention of 1926 as amended;

- The Supplementary Convention on the Abolition of Slavery, the Slave Trade, and Institutions and Practices Similar to Slavery;

- The Convention against Torture and Other Cruel, Inhuman or Degrading Treatment of Punishment;

- The Geneva Convention Relative to the Treatment of Prisoners of War (the $3^{\text {rd }}$ Geneva Convention);

- The Geneva Convention Relative to the Protection of Civilian Persons in Time of War (the $4^{\text {th }}$ Geneva Convention);

- The Protocol Additional to the Geneva Conventions of 12 August 1949, and Relating to the Protection of Victims of International Armed Conflicts (Protocol I);

- The Protocol Additional to the Geneva Conventions of 12 August 1949, and Relating to the Protection of Victims of Non-International Armed Conflicts (Protocol II);

- The International Convention on the Elimination of All Forms of Racial Discrimination;

- The Convention and Protocol Relating to the Status of Refugees;

- The Convention Governing the Specific Aspects of Refugee Problems in Africa;

- The Convention on the Rights of the Child and Optional Protocol on Involvement of Children in Armed Conflicts;

- The International Covenant on Civil and Political Rights;

- The International Covenant on Economic, Social and Cultural Rights; and

- The African Charter on Human and Peoples' Rights.

\section{THE ACCUSED}

1. OMAR HASAN AHMAD AL-BASHIR as the President of Sudan is the "supreme commander of the People's Armed Forces and other regular forces" pursuant to Article 43 of the Sudanese Constitution. Accordingly, AL-BASHIR is the highest authority with respect to strategic military matters, internal security, and the deployment of armed and police forces within the Sudan. Thus, at all relevant times, AL-BASHIR exercised effective command, authority, and control over the groups and individuals who directly committed the crimes set forth in this Indictment. In addition, and in the alternative, AL-BASHIR aided, abetted, conspired with, shared a common purpose with, and/or entered into a joint criminal enterprise with the individuals and groups that directly committed the crimes set forth in this Indictment.

2. AL-BASHIR was born in the village of Hosh Bannaga in 1944. He joined the Sudanese Army at a young age and studied at a military academy in Cairo, Egypt.

3. When he returned to the Sudan, AL-BASHIR assumed responsibilities for military operations against the Sudanese People's Liberation Army (SPLA) in the southern half of the country during the Second Sudanese Civil War between the central government in the north and rebel groups in the south. The SPLA and its political wing, Sudan People's Liberation Movement (Al-Harakat Ash-Shaabia Le Tahreer As-Sudan), have for years advocated a "New Sudan" based on respect for human rights and democracy. The SPLA was commanded by John Garang until his death on July 30, 2005. 
4. AL-BASHIR eventually obtained the rank of Lieutenant General. In 1989, he was involved in a military coup that overthrew democratically elected Prime Minister Sadeq alMahdi. AL-BASHIR immediately began implementing the repressive policies that have become the hallmark of his reign of terror, including a ban on all political parties, a press crackdown, and the dissolution of Parliament. AL-BASHIR then became Chairman of the Revolutionary Command Council for National Salvation (RCC), which consisted of fifteen military officers who had joined AL-BASHIR in carrying out the 1989 coup and which assumed all legislative and executive powers over the country. This entitled AL-BASHIR to the posts of Chief of State, Prime Minister, Chief of the Armed Forces, and Minister of Defense.

5. AL-BASHIR, allied with Hassan al-Turabi, the leader of the National Islamic Front (NIF) political party, began making northern Sudan a fundamentalist Islamic state. The NIF extended Sharia law and created the Public Order Police. On October 16, 1993, AL-BASHIR was appointed President of the Republic of Sudan by the RCC. He then dissolved the RCC and transferred its legislative and executive powers to himself. AL-BASHIR has ruled the nation as a virtual dictator from that point on. In 1996, AL-BASHIR was elected to a five-year term as President in a "showcase" election. Hassan al-Turabi also won a seat in the National Assembly as a result of the election and was later named its Speaker. In 1998, AL-BASHIR and the Presidential Committee put into effect a new Constitution. Although some limited political associations are allowed by law, these groups have failed to gain any significant access to governmental power.

6. In 1999, Hassan al-Turabi sought to limit the President's power by empowering the National Assembly to remove him from office if it deemed necessary and by reestablishing the office of Prime Minister. In response, AL-BASHIR declared a national state of emergency, suspended the nation's Constitution, dissolved the National Assembly, and stripped al-Turabi of his governmental and party posts. Shortly thereafter, in 2000, AL-BASHIR removed all alTurabi loyalists from his cabinet and replaced them with his own followers. A general election was held later that year; however, the election was boycotted by almost all opposition groups who contended that AL-BASHIR would simply fix the results of the election if he lost. Most Sudanese in the south were furthermore prohibited from voting by the Sudan People's Liberation Army. Therefore, while AL-BASHIR won re-election as President and the Parliament became stacked with members of his National Congress Party, the victory was hardly a legitimate one. As his second presidential term nears an end, AL-BASHIR is now seeking to change a provision in the Sudanese Constitution that would otherwise prohibit him from seeking re-election. It should also be noted that the state of emergency which AL-BASHIR declared in 1999 is still in effect to this day, leaving essentially all governmental power with the President. AL-BASHIR, as the supreme executive of Sudan, consistently represents the country on the international plane in international conferences and negotiations. It is recognized that change will only occur in Sudan if AL-BASHIR consents to such change.

7. In his capacity as chief of the ruling Revolutionary Command Council and then as President, AL-BASHIR exercised effective command and control over all members of the armed and police forces of the Government of Sudan and all agencies of the state, including the regular army and air force units, Popular Defense Forces, and State Security Forces, which are 
variously designated as Military Intelligence, and Intelligence and Security Forces. In addition, the accused exercised effective command or control over - or in the alternative aided and abetted and shared a common purpose with-armed militia, such as the janjaweed who, working in coordination with Sudanese armed forces, are responsible for massacre, rape, and forced displacement in Darfur and elsewhere.

\section{STATEMENT OF FACTS}

8. AL-BASHIR is in exclusive command and control of a military apparatus whose constitutional mandate includes the maintenance of internal security. The Sudanese government forces include the Sudan People's Armed Forces, which are comprised by an army, navy and air force. These regular armed forces are supplemented by the Popular Defense Forces, consisting of civilians who are called to military duty when needed. The Sudanese government also employs several intelligence organs such as Military Intelligence, Borders Intelligence, and the National Security and Intelligence Service. While each of these organs technically exists independent of the regular armed forces, Sudanese intelligence forces have worked closely on the ground with the regular armed forces, providing them with information that they used as the basis for operational planning.

9. As President, AL-BASHIR sits at the highest level in the command structure of these Sudanese governmental forces and is the ultimate authority on all tactical decisions concerning the waging of war and internal security. For example, in the case of the Sudan People's Armed Forces, tactical decisions and policy are made by a Command Group, consisting of a Commander of the Armed Forces, a Chief of General Staff, and five Deputy Chiefs of Staff. The Command Group reports to the Minister of Defence, who in turn, reports to the President. In the case of the intelligence organs, the head of each organ is directly accountable to the Presidency.

10. AL-BASHIR has mobilized and deployed this vast military apparatus against various minority tribal groups in Sudan, including the Fur, Massaleit, Zaghawa, Tunjur, and Dajo of Darfur; the peoples of the Nuba Mountains; the Nuer people; the Dinka people; the people of the Shilluk Kingdom; and the Beja people of East Sudan as set forth in more detail below.

\section{CRIMES COMMITTED AGAINST THE PEOPLE OF DARFUR}

11. In February 2003, loosely federated rebel groups, calling themselves the Sudan Liberation Movement/Army (SLM/A) and the Justice and Equality Movement (JEM), declared open rebellion against the Government of Sudan because they were excluded from the powerand wealth-sharing agreements emerging from North-South peace negotiations in connection with the Second Sudanese Civil War. The Government responded with a counter-insurgency campaign directed primarily at civilian targets. This campaign coincided with the emergence on the international scene of the janjaweed-roving militia on horse- and camelback with deniable ties to the central authorities.

12. The janjaweed have worked in close coordination with Sudanese land and air forces to empty, plunder, and destroy over 1000 villages in North and South Darfur. The violence and destruction of everyday life is staggering. Janjaweed and government troops have systematically 
murdered, raped, mutilated, starved, driven from their homes, and robbed of all their possessions, including more than 2 million head of livestock, Non-Arab (and non-combatant) Darfuris of the Fur, Massaleit, Zaghawa, Tunjur, Dajo, and other tribes. These combined and coordinated forces have destroyed hundreds of mosques, targeted imams, and in several instances killed all the men of a village as they prayed together.

13. The high degree of violence in Darfur led the United Nations Security Council by Resolution 1564 to direct the Secretary-General to form a Commission of Inquiry to "investigate reports of violations of international humanitarian law and human rights law in Darfur by all parties, to determine also whether or not acts of genocide have occurred, and to identify the perpetrators of such violations with a view to ensuring that those responsible are held accountable." During November 2004 and January 2005, the Commission sent investigative teams to Sudan to hold meetings with representatives of the Government, the Governors of the Darfur States and other senior officials in the capital and at provincial and local levels, members of the armed forces and police, leaders of rebel forces, tribal leaders, internally displaced persons, victims and witnesses of violations, NGOs, and United Nations representatives. On January 25, 2005, the Commission issued its Report, which found that the Government of Sudan was responsible for crimes against humanity and war crimes on a mass scale in Darfur. Although it could not conclude that the government had implemented a policy of genocide, the Commission did reserve consideration of whether individual members of the government, armed forces, or armed militia may have harbored and acted with genocidal intent.

14. The International Commission of Inquiry on Darfur also reported in January 2005 that of a total population of 6.3 million in a region the size of France, more than 1.65 million were internally displaced and another 200,000 had fled to neighboring nations such as Chad, where they had become refugees. The United Nations High Commissioner on Refugees stated in its most recent report on the region that, because of the "rapidly deteriorating situation" in Darfur, the number of refugees and internally displaced persons grew at an alarming rate during 2005. The number of refugees and internally displaced persons in the region is therefore undoubtedly now much higher than the already alarming numbers reported by the Commission. The International Commission of Inquiry on Darfur cited hundreds of reported incidents involving the killing of civilians, massacres, summary executions, rape and other forms of sexual violence, torture, abduction, looting of property and livestock. The Commission furthermore reported that government and janjaweed attacks have destroyed hundreds of villages and hamlets. Tens of thousands of innocent civilians have died as a result of these attacks. Furthermore, with their farms, villages, and livestock destroyed and with humanitarian personnel unable to deliver the food and medical assistance, hundreds of thousands more have fallen prey to conditions of famine and disease. As a result, prominent NGOs such as Amnesty International have recently estimated that the conflict in the region has directly or proximately caused as many as 285,000 deaths, while other experts argue that the number is as high as 450,000. These numbers continue to rise as this Indictment is issued.

15. The previous fall, Vice President Ali Osman Taha had warned rebels of "total destruction," a genocidal goal echoed by militia leader and Government of Sudan agent Musa Hilal, who directed his forces to "change the demography of Darfur and empty it of African [i.e., non-Arab] tribes." These statements have proved to be chillingly prescient. 


\section{CRIMES COMMITTED AGAINST THE NUBA PEOPLE}

16. Subsequent to the coup of June 1989, the Sudanese leadership began a campaign against the 1.3 million members of the Nuba tribe in South Kordofan province. Between 1989 and 1991, scores of villages were burned and thousands of villagers were killed in joint assaults by the Government of Sudan army and locally recruited militias.

17. In 1991, educated Nuba became a special target of wholesale arrests, executions, and "disappearances." In 1992, the Government of Sudan declared a jihad. AL-BASHIR took the title of imam al jihad (spiritual leader of the holy war) and bestowed subordinate leadership titles on Arab tribal leaders. The Government of Sudan Vice President, Zubeir Mohammed Salih, moved his headquarters to Kordofan to insure close supervision of operations. The Governor of South Kordofan, Lt.-General Abdel Karim el Husseini, was distinguished by the zealotry with which he enforced the fatwa decree of April 1992 in support of the jihad, despite protests from other government officials who pointed out that many of the intended victims were Muslims. The forces under Gen. Salih and other units of the Sudanese army and militias systematically killed Nuba civilians of all religious allegiances, including Muslims. These forces also destroyed mosques and churches and desecrated Bibles and Korans.

18. Along with attacks against these embodiments of Nuba culture, Government forces deliberately attacked the non-Arab civilian population, using tear gas to force them out of caves and starvation to force entire villages to surrender. Those interned in "peace camps" were forced to work on mechanized farms for token wages, and many women were kept against their will as "wives" for the soldiers.

\section{CRIMES COMMITTED AGAINST THE DINKA PEOPLE}

19. Throughout his rule, AL-BASHIR escalated the Second Sudanese Civil War by launching scorched earth attacks against the southern region. These attacks involved numerous war crimes, crimes against humanity, and other human rights violations including the deliberate targeting of civilians and civilian infrastructure and the murder, torture, and rape of civilians. The civil war also resulted in millions of southerners being displaced, starved, and deprived of education and health care.

20. Because of these actions, various international sanctions were placed on the Sudan. Nevertheless, AL-BASHIR pursued the war in the south, buying arms and funding military operations with money eventually gained from the sale of the country's vast amounts of petroleum resources from 1999 onward. Under intense international pressure, the Government of Sudan finally agreed to peace talks in 2002, and a peace agreement was signed in 2005. In this agreement, AL-BASHIR agreed to grant limited autonomy to the south for six years, split the proceeds from the country's oil revenues with the southern provinces, and allow the southerners to vote in a referendum of independence at the end of the six year period.

21. The Dinka are a tribal group located in the South of the country. Following the June 1989 coup by the National Islamic Front, attacks on the Dinka continued, with individuals being targeted for starvation, slavery, and persecution by the Sudanese leadership. As the largest ethnic 
group in the South, the Dinka practice an agro-pastoral lifestyle upon lands with vast oil reserves. Along with their animist religious beliefs, the Dinka are seen as a threat to the government's dual policy of expansion over the South's oil-rich areas and Islamization of the South's indigenous groups.

22. From 1989-1993, the Government of Sudan armed militias composed of Arab murahaleen-Arab tribesmen with a historic enmity against the neighboring Dinka tribe. With this government's blessing, murahaleen razed the crop lands and looted the cattle that form the livelihood of the Dinka. These attacks intensified famine conditions that originated in 1983 with the Nimeiri regime, resulting in the deaths of 1.5 million southerners, the majority belonging to the Dinka.

23. Between 1992 and 1995, widespread abductions of Dinka women and children ensued in the South, while Dinka families who had fled to Khartoum were kidnapped or otherwise coerced into camps. It was widely reported by prominent NGOs such as Human Rights Watch that many of the abductions of the Dinka people were perpetrated by murahaleen militias who had been armed by the Government of Sudan. The murahaleen led a campaign of widespread destruction of Dinka villages, and the residents of those villages were collected as "spoils" by the murahaleen raiders. Their captors would then force them to take Arab names, subject them to living conditions far below their own, and deprive them of education. Many Dinka were forced by their captors to convert to Islam. When the Government of Sudan drew criticism for this practice, it denied its ties to the murahaleen and furthermore insisted that the matter was one of hostage-taking between rival tribes and that it had little power to combat the problem.

24. Between 1994 and 1997, the Government of Sudan sponsored the forces of Kerubino Bol, a former SPLA commander, in their attacks against rural Dinka communities in the Upper Nile region. By the end of 1997, continuous looting and forcible displacement had left approximately 250,000 at risk of starvation.

25. After Bol's defection to the SPLA in late January 1998, and his subsequent attempt to capture government garrisons around the towns of Wau and Juba, the Government of Sudan embarked on a vengeful campaign against the Dinka population in these areas. During the fighting at Wau and for ten days after, government forces scoured Dinka neighborhoods and marketplaces, searching for civilians hiding in these areas as well as in the local hospital and public buildings. On February 18-19, at least 600 mostly Dinka men, women and children were killed by a combination of government military forces, local Fertiit militia, and Popular Defense Forces. According to a U.N. on-the-spot investigation, hundreds of bodies were found scattered in the streets and dumped into the Jur River. In addition, the Government of Sudan banned all relief flights into the SPLA-held region of Bahr-el-Ghazal until the end of March 1998 as a means to punish Bol's forces and the inhabiting civilians. This ban marked a clear example of the Sudanese government using starvation against a civilian population.

\section{CRIMES COMMITTED AGAINST THE PEOPLE OF THE SHILLUK KINGDOM}

26. Despite its largely Christian population, and its leadership under a non-Muslim king, the Shilluk kingdom remained free from government persecution until 2004. Situated in the Midwest 
Upper Nile, one of Sudan's potentially leading oil-producing areas, the kingdom was formerly secured by Nuer militias aligned with the Government of Sudan. On October 25, 2003, however, Khartoum's control over the region unraveled when Lam Akol, the leader of a government-allied militia within Shilluk, defected to the SPLA. In retaliation, the Sudanese government began conducting numerous attacks on the kingdom in conjunction with Nuer and other militia groups.

27. Beginning on March 5, 2004 in the town of Owechi, the Government of Sudan sponsored attacks that were initially limited in scope against military officers and associates of Lam Akol who had joined the defection to the SPLA. But by the end of March, the military campaign transformed into a spree of indiscriminate looting and killing of civilians throughout the kingdom. On March 28, militias from the government garrison in Warjog arrived in the village of Datang and began burning down the homes of civilians suspected of sympathizing with Akol and the SPLA. According to the Civilian Protection Monitoring Team (CPMT), a U.S. State Department-funded investigative unit which consisted of investigative teams, run jointly by the SPLA and the Sudanese Army, 700-800 mostly Nuer militiamen came equipped with two machine-gun mounted Land Cruisers, and proceeded to burn homes, grain stocks and medical provisions. Witnesses reported that the militias were directed by Sudanese army officers, including Commander James Othow, a brigadier in the Sudanese army who also served as the commissioner of Tonga County within the kingdom.

28. Just days later, these same militias-emerging in three groups - returned for a second assault upon the village of Datang. CPMT reported that a main force arrived from the direction of Leno, a Government of Sudan-controlled town, and that a barge transported the aforementioned Land Cruisers under Othow's command. Three other Sudanese army commanders were reported to have been transported by government military motorboats from Malakal, the main town in the southern part of the kingdom. These commanders were Joseph Mobutu, Thomas Mabor and Gabriel Tanginya, who also held the rank of Brigadier General in the Sudanese army. In a thinly veiled denial of the attacks, Lt. Hamdun Da'ud, the Sudanese army commander in Datang, stated that militia forces were "only passing through" the village around March 28, but claimed "drunken bandits" had burned homes, adding that "civilians sometimes wear army uniforms."

29. Beyond Datang, attacks on villages spanned from Owechi to Papwojo along the southern border of the kingdom. In these attacks, more civilians were killed, homes and sorghum stores were razed, and cattle were looted. These attacks displaced over 100,000 individuals without food or shelter. Terrorized by the indiscriminate shooting of civilians and burning of entire villages along the White Nile River, those displaced were prevented from returning to their homes until after the signing of the Comprehensive Peace Accord between the Sudanese government and the SPLA in January 2005.

\section{INDIVIDUAL CRIMINAL RESPONSIBILITY}

30. AL-BASHIR is individually criminally responsible for the crimes set forth above through theories of common purpose/joint criminal enterprise, superior (command) responsibility, and criminal complicity. The accused planned, instigated, ordered, committed, was complicit in, or otherwise aided and abetted in the planning, preparation, or execution of the 
crimes charged. For the modes of liability of planning, instigating, or ordering the crimes charged, the accused acted with the intention and awareness of the substantial likelihood that the crimes would be committed in the execution of the plan, order, or instigation. For the mode of liability of aiding and abetting, including the provision of means for the crimes' commission, the accused acted with knowledge that the acts performed would assist in the commission of the crimes.

31. The Prosecutor does not allege that AL-BASHIR physically or personally committed all the crimes charged, nor do international law or the Statute of this Tribunal so require. "Committing" in this Indictment instead refers to intentional or knowing participation as coperpetrator, either as an accomplice, as a member of a joint criminal enterprise, as a member of a group sharing a common criminal purpose, or as a superior exercising effective authority, command, and control over subordinates. In contributing to the commission of the crimes charged, the accused intended to further the criminal activity or common purpose of the group or individuals directly responsible for committing the crimes within the jurisdiction of this Tribunal. In the alternative, the accused knew of the criminal intent of the group or individuals actually responsible for these acts and knowingly and purposefully contributed to the criminal purpose.

\section{COMMON PURPOSE}

32. Upon gaining power over the Sudanese government in 1989, the accused immediately formed a joint criminal enterprise that continues into the present. A number of individuals participated in this joint criminal enterprise during the entire duration of its existence, or, alternatively, at different times during the duration of its existence, including:

- OMAR AL-BASHIR,

- Ali Osman Taha,

- Salah Abdallah Gosh, head of the Security Services;

- Muhammed Hussein;

- Musa Hilal.

Other members included unidentified persons who were members of the government's command and coordinating bodies, members of the armed forces of the Government of Sudan at all levels of the chain of command, and members of the janjaweed and other paramilitary forces who shared the intent to affect the common purpose of the joint criminal enterprise. This includes the head of the Popular Defense Forces, the head of the Intelligence Service, individuals occupying the governorships of the Darfur and other provinces, police heads, the heads of some Sudanese humanitarian organizations that are actually staffed by Security Service personnel, command of janjaweed militias, and command of the Border Guards. In addition, it includes high level personnel of the Revolutionary Command Council, the National Islamic Front, and the National Congress Party.

33. AL-BASHIR has, at all times since 1989, held the highest position within the Government of Sudan and been the commander-in-chief of the Sudanese armed forces. The accused therefore sat at the center of the joint criminal enterprise. AL-BASHIR, together with 
his co-perpetrators, participated in the planning and execution of numerous crimes within the subject-matter jurisdiction of this Tribunal. The crimes alleged above were perpetrated as part of a common plan to employ criminal means to systematically eliminate the tribes and ethnic groups mentioned above, either because they were viewed by the Government of Sudan as an impediment to the creation of an entirely Islamic state, or because the Sudanese government perceived them as a threat to its exercise of autocratic power.

34. AL-BASHIR worked in concert with members of the Government of Sudan, the Sudan People's Armed Forces, and other militias and police forces to design and implement a widespread and systematic campaign of terror and repression directed at certain minority political, religious, and ethnic groups, in particular the so-called "African" tribes. The means employed as a part of this common plan and joint criminal enterprise included deportations and forcible transfers of members of these groups; enslavement; torture; rape; persecution; the destruction of property belonging to members of the group; pillage; the forcible transfer of children of these groups; the imposition of measures to prevent births within these groups; and the deliberate infliction of conditions of life calculated to bring about the physical destruction, in whole or in part, of these groups. AL-BASHIR exercised his de facto and de jure authority as the President of the Republic of Sudan and Commander-in-Chief of the armed forces to order and ensure that this criminal plan would be carried out.

35. The civilian populations targeted by this joint criminal enterprise include, but are not limited to, the following:

- The Fur of Darfur

- The Massaleit of Darfur

- The Zaghawa of Darfur

- The Tunjur of Darfur

- The Dajo of Darfur

- The peoples of the Nuba Mountains

- The Dinka people

- The people of the Shilluk Kingdom

- The Beja people of East Sudan

36. These groups constitute national, ethnic, racial, and/or religious groups within the definition of genocide set forth within the 1948 Genocide Convention, contained within customary international law, and incorporated within Article 6 of the Statute of this Tribunal. Victims from these groups were civilians, unconnected to formal armed forces and uninvolved in any armed conflict other than as victims. As such, they constituted "protected persons" within 
the meaning of the Geneva Conventions and their Protocols, as incorporated within Article 8 of this Statute. In addition, attacks on these groups constituted a widespread and systematic "attack directed against any civilian population" within the definition of the prohibition against crimes against humanity set forth within Article 7 of the Statute of this Tribunal.

37. The crimes that are the subject of this Indictment were within the object of the joint criminal enterprise or the common purpose of the group, and the accused shared the intent with the other co-perpetrators that these crimes be perpetrated. Alternatively, these crimes were the natural and foreseeable consequences of the execution of the object of the joint criminal enterprise, and AL-BASHIR was aware that such crimes were the possible outcome of the enterprise. Despite his awareness of the foreseeable consequences, AL-BASHIR initiated and participated in the enterprise. The accused and other participants in the joint criminal enterprise shared the intent and state of mind required for the commission of each of the crimes charged. In the alternative, the accused and other participants in the joint criminal enterprise knew with substantial certainty that the crimes outlined above would be committed by other members of the joint criminal enterprise. On this basis, AL-BASHIR bears individual criminal responsibility for the crimes alleged in this Indictment under Article 25(3)(d)(i) of the Statute of this Tribunal.

\section{AIDING AND ABETTING}

38. Many of the atrocities perpetrated against the Sudanese civilian populations were carried out by janjaweed, murahaleen and other ethnic Arab militias. While these militias are not formally part of the infrastructure of the Sudanese military, it has been noted by the International Commission of Inquiry on Darfur, several prominent NGOs, and international observers that such militias often work at the direction and with the active support of the Government of Sudan, including with respect to the provision of means (weapons, transportation, and other materiel). Furthermore, the Commission on Darfur noted that the janjaweed militias were, at times, armed by the Popular Defense Forces and worked in coordination with regular armed forces. In addition, janjaweed leaders received compensation in the form of grants and gifts from the Sudanese government. To date, the Sudanese government has failed to apprehend and bring to justice the members of janjaweed militias who are responsible for the crimes in Darfur. Instead, the Government of Sudan has effectively condoned the janjaweed actions by creating a sham investigative and judicial framework that is intended to divest the International Criminal Court of jurisdiction over the crimes committed by the janjaweed, but which has made no appreciable effort to actually bring the perpetrators to justice.

39. AL-BASHIR oversees a government that actively supports groups that are directly responsible for perpetrating crimes that are within the subject-matter jurisdiction of this Tribunal. The accused furthermore provided such support to the janjaweed militias even after being provided with actual knowledge that such crimes were being committed. This is evidenced by the U.N. Security Council's repeated requests to the Government of Sudan that the janjaweed militias be disarmed and the perpetrators brought to justice. The accused instead responded to these requests by providing further support to the janjaweed militias in the form of false investigative and judicial organs. Accordingly the accused aided and abetted the atrocities committed by the janjaweed militias and bears individual criminal responsibility under Article 25(3)(c) of the Statute of this Tribunal. 


\section{SUPERIOR RESPONSIBILITY}

40. AL-BASHIR, while holding positions of superior authority, is also individually criminally responsible for the criminal acts or omissions of his subordinates pursuant to Article 28 of the Statute of the Tribunal. A superior is responsible for the criminal acts of his subordinates if he knew or had reason to know that his subordinates were about to commit such acts or had done so, and the superior failed to take the necessary and reasonable measures to prevent such acts or to punish the perpetrators.

41. Pursuant to Article 43 of the Sudanese Constitution, the President is the "supreme commander of the People's Armed Forces and other regular forces." Accordingly, as President, AL-BASHIR was the highest authority with respect to strategic military matters and the deployment of armed forces within the Sudan. Notwithstanding any explicit de jure power ALBASHIR might have possessed over the Sudanese military, the accused exercised de facto authority over all Sudanese military forces beginning with the 1989 coup. Thus, at all relevant times, AL-BASHIR exercised effective command, authority, and control over the groups and individuals who directly committed the crimes set forth in this Indictment. There existed a functioning chain of command within the Government of Sudan that ensured that command and control ran from the highest levels of government in Khartoum to all armed forces in the field. The accused - along with other unindicted members of the Government of Sudan-formulated strategy, issued directions, and commanded operations by forces throughout Sudan. ALBASHIR has been, at all times, in a position to control the activities of the armed forces of the Government of Sudan and to punish violations of international criminal law.

42. At all times relevant to this Indictment, AL-BASHIR knew, should have known owing to the circumstances of at the time, or consciously disregarded information which clearly indicated that subordinates were committing, had committed, or were about to commit crimes within the jurisdiction of this Tribunal. The accused was informed of the widespread and systematic crimes being committed by government and paramilitary forces under his effective command, authority, and control through, among other things, the reporting systems of the armed forces of the Government of Sudan and his meetings with members of the highest levels of civilian and military leadership of the Government. In addition, there has been widespread reporting from many sources about crimes committed by armed forces under the effective authority, command, and control of the accused. These allegations were also publicly and prominently raised by, among others, foreign diplomats, the United Nations, human rights organizations, and the domestic and foreign media. These reports include the following:

- "Darfur in Flames: Atrocities in Western Sudan," A Human Rights Watch Report, April 2004;

- "Darfur Destroyed: Ethnic Cleansing by Government and Militia Forces in Western Sudan," A Human Rights Watch Report, May 2004;

- "Darfur Documents Confirm Government Policy of Militia Support," A Human Rights Watch Briefing Paper, July 19, 2004;

- "Empty Promises? Continuing Abuses in Darfur, Sudan," A Human Rights Watch Briefing Paper, August 11, 2004; 
- "If We Return We Will Be Killed," A Human Rights Watch Briefing Paper, November 15, 2004;

- "Targeting the Fur: Mass Killings in Darfur," A Human Rights Watch Briefing Paper, January 24, 2005;

- "Sexual Violence and its Consequences among Displaced Persons in Darfur and Chad," A Human Rights Watch Briefing Paper, April 12, 2005;

- "Entrenching Impunity: Government Responsibility for International Crimes in Darfur," A Human Rights Watch Report, December 2005;

- Amnesty International, "Sudan: At the Mercy of Killers-Destruction of Villages in Darfur," July 2, 2004.

- "Alarming Situation of Human Rights and Dramatic Humanitarian Crisis in Darfur," FIDH, April 13, 2004;

- "Ongoing Harassment of Human Rights Defenders," FIDH, November 7, 2005;

- "Peace and Justice in Darfur: Victims' Rights Hijacked," FIDH, April 3, 2006;

- "Human Rights and Humanitarian Organizations at Risk in Sudan," FIDH, March 3, 2006.

- "Slavery and Slavery Redemption in the Sudan," A Human Rights Watch Background Paper, March 12, 1999.

- "In the Name of God: Repression Continues in Northern Sudan," A Human Rights Watch Report, November 1994.

43. Additional notice of abuses by subordinates and others came from the United Nations International Commission of Inquiry on Darfur. In its comprehensive report, the Commission concluded that crimes within the jurisdiction of this Tribunal were widespread within Darfur and were attributable to government forces and janjaweed forces working together with government forces.

44. The crimes set forth in this Indictment are within AL-BASHIR's effective responsibility and control as President of Sudan. At all times relevant to this Indictment, AL-BASHIR failed to exercise responsible command and control over subordinate forces. In particular, the accused failed to take all necessary and reasonable measures within his power to prevent or repress the commission of crimes within the jurisdiction of this Tribunal. For example, in Darfur, ALBASHIR failed to utilize the military and police forces to control or disarm the janjaweed forces. On the contrary, it has widely been noted by civil society groups and the report of the International Commission of Inquiry on Darfur that the janjaweed militias conducted attacks against civilian groups at the behest of the Sudanese government and often acted in concert with Government of Sudan aircraft. Furthermore, the janjaweed tribal leaders often received compensation from the Sudanese government in the form of grants and gifts.

45. Furthermore, AL-BASHIR failed to submit any of the crimes set forth in this Indictment to the competent authorities for investigation and prosecution. With respect to the abuses in Darfur, the accused did act in his official capacity to create judicial and investigative mechanisms such as the Judicial Investigations Committee, the Special Prosecutions Commissions, and the Darfur Special Court. All these institutions were ostensibly intended to answer the demands of the Security Council, civil society groups, and the international community that the Government of Sudan apprehend and bring to justice those responsible for 
the ongoing atrocities in that nation. However, civil society groups such as Human Rights Watch, the Office of the Prosecutor of the International Criminal Court, and the United Nations High Commissioner on Human Rights each noted in official statements that these mechanisms do not represent a genuine effort on the part of the Sudanese government to exact justice, as there is little evidence that they have carried out their mandates in any appreciable way.

46. In March 2005, the Security Council passed Resolution 1593, which referred the situation in Darfur to the International Criminal Court whose Prosecutor then initiated an investigation into the situation. The Rome Statute, the Court's constitutive document, operates on the principle of complementarity and is prohibited from commencing a prosecution if the state in which the crimes allegedly occurred has demonstrated a genuine willingness and ability to prosecute the crimes domestically. The creation of these bodies by the Government of Sudan therefore appears to be little more than a paper maché effort to mollify international critics and divest the International Criminal Court of jurisdiction. Accordingly, by failing to genuinely investigate and prosecute the crimes committed against these victim groups, AL-BASHIR effectively encouraged the continued commission of such crimes and failed to exercise responsible leadership and command. This inaction and impunity have created and maintained an environment permissive of criminal behavior that continues today.

47. For purposes of the crimes enumerated in this Indictment, the accused can be considered a military commander within the meaning of Article 28(a) of the Statute of this Tribunal. Because AL-BASHIR exercised effective command and control over Sudanese military forces at all times relevant to this Indictment, and because he knew or should have known of the crimes enumerated in this indictment which were committed by Sudanese military forces, and because the accused failed - despite repeated requests by the Security Council - to take all necessary and reasonable measures within his power to prevent or repress the commission of crimes or to submit the matter to the competent authorities for investigation and prosecution, the accused bears individual criminal responsibility for their commission as under the Doctrine of Command Responsibility, as codified in Article 28(a)(i) and (ii) of the Statute of this Tribunal.

48. Alternatively, in the event that this Tribunal might conclude that AL-BASHIR is a civilian superior, and not a military commander, the accused still bears individual responsibility under Article 28(b)(i), (ii) and (iii) of the Statute of this Tribunal. In most instances, the accused can conclusively be presumed to have known that the crimes enumerated in this indictment were being committed by his subordinates, as they were carried out at his direction. The crimes enumerated in this Indictment were also well-documented and widely reported by civil society groups. Furthermore, the Security Council implored the accused on several occasions to apprehend and bring to justice the parties responsible for perpetrating the atrocities in the Darfur region. The accused was also aware of the conclusions by the International Commission of Inquiry on Darfur that crimes against humanity and war crimes were being committed in the Darfur region and that such atrocities were possibly being committed with genocidal intent. The accused therefore undoubtedly had actual knowledge of the crimes enumerated in this indictment and, at best, consequently disregarded and failed to act upon information that clearly indicated that criminal activity within the subject-matter of this Tribunal was being committed by his subordinates and was likely to continue. 
49. At all times relevant to this indictment, AL-BASHIR exercised de facto and de jure control over the Government of Sudan and over Sudanese military forces; therefore, any crimes attributable to these entities were committed within the effective responsibility of the accused. As noted above, the accused furthermore failed to utilize his authority to repress the commission of these crimes or submit the matter to the competent authorities for investigation and prosecution. Therefore, while the Prosecutor does not contend that the accused is a civilian superior under the Statute of this Tribunal, the accused nonetheless bears individual criminal responsibility as such, should this Tribunal so find.

\section{CHARGES}

50. The Prosecutor hereby charges the accused with CRIMES AGAINST HUMANITY, WAR CRIMES, and GENOCIDE for the crimes set forth above.

\section{CRIMES AGAINST HUMANITY}

51. By these acts and omissions in all the regions discussed above with respect to the Darfuri, Nuba, Dinka, and Shilluk people, AL-BASHIR planned, instigated, ordered, committed, or otherwise aided and abetted the planning, preparations or execution of:

Count 1: EXTERMINATION, a CRIME AGAINST HUMANITY punishable under Article 7(1)(b) of the Statute of the Tribunal.

Count 2: MURDER, a CRIME AGAINST HUMANITY punishable under Article 7(1)(a) of the Statute of the Tribunal.

Count 3: PERSECUTION, a CRIME AGAINST HUMANITY punishable under Article 7(1)(h) of the Statute of the Tribunal.

Count 4: DEPORTATION, a CRIME AGAINST HUMANITY punishable under Article 7(1)(d) of the Statute of the Tribunal.

Count 5: RAPE and SEXUAL VIOLENCE, CRIMES AGAINST HUMANITY punishable under Article 7(1)(g) of the Statute of the Tribunal.

Count 6: TORTURE, a CRIME AGAINST HUMANITY punishable under Article 7(1)(f) of the Statute of the Tribunal.

52. From 1989 until the present, AL-BASHIR, acting individually or in concert with other participants in the joint criminal enterprise, planned, instigated, ordered, committed or otherwise aided and abetted the planning, preparation or execution of the extermination, murder, persecution, deportation, rape, and abuse of members of minority racial, religious, ethnic, and political groups.

53. Government and paramilitary forces under the effective authority, command, and control of AL-BASHIR, committed these crimes against humanity. AL-BASHIR knew or had reason to 
know that the crimes alleged above were about to be committed or had been committed by his subordinates, and he failed to take necessary and reasonable measures to prevent such acts or punish the perpetrators thereof.

54. Where armed militia without formal ties to governmental forces committed the crimes, the Government of Sudan at AL-BASHIR's direction and under AL-BASHIR's command and control gave substantial assistance to these militia. AL-BASHIR knew that the assistance provided by the Government of Sudan and by governmental armed forces in the form of weapons, transportation, air support, and materiel to armed militia would substantially contribute to the commission of the crimes charged above.

\section{ENSLAVEMENT}

55. By the acts and omissions with respect to the Dinka people as discussed above ALBASHIR planned, instigated, ordered, committed, or otherwise aided and abetted the planning, preparations or execution of:

\section{Count 7: ENSLAVEMENT, a CRIME AGAINST HUMANITY punishable under Article 7(1)(c) of the Statute of the Tribunal.}

56. AL-BASHIR, acting individually or in concert with other known and unknown members of the joint criminal enterprise planned, instigated, ordered, committed, or otherwise aided and abetted in the planning, preparation, or execution of the enslavement of members of the Dinka people.

57. Government and paramilitary forces under the effective authority, command, and control of AL-BASHIR, committed acts of enslavement against the Dinka people. AL-BASHIR knew or had reason to know that the crimes alleged above were about to be committed or had been committed by his subordinates, and he failed to take necessary and reasonable measures to prevent such acts or punish the perpetrators thereof.

\section{GENOCIDE}

58. By these acts and omissions in Darfur and with respect to the Dinka and Nuba people, AL-BASHIR planned, instigated, ordered, committed, or otherwise aided and abetted the planning, preparations or execution of:

\section{Count 8: $\quad$ GENOCIDE.}

59. AL-BASHIR, acting individually or in concert with other participants in the joint criminal enterprise, planned, instigated, ordered, committed or otherwise aided and abetted the planning, preparation or execution of the intentional partial destruction of these minority tribal groups.

60. AL-BASHIR participated in a joint criminal enterprise whose main objective was primarily achieved through a manifest pattern of persecutions as alleged in this indictment. This 
campaign of persecutions included or escalated to include conduct committed with the intent to destroy in part national, ethnical, religious and/or racial groups in Darfur associated with the rebel forces there. Government forces under the command and control of AL-BASHIR targeted a significant part of these tribal groups for intended destruction.

61. The destruction of these groups was effectuated by:

- The widespread killing, deportation, and forcible transfer of members of these groups during and after the attacks on villages. Members of these groups were killed and hundreds of thousands deported or forcibly transferred in furtherance of an "ethnic cleansing" campaign in Darfur. A large segment of these tribal groups were driven into displaced person camps in Sudan or across the border into Chad.

- The causing of serious bodily or mental harm to members of these groups. Members of these tribal groups in these villages were subjected to cruel or inhumane treatment, including torture, physical and psychological abuse, sexual violence and beatings.

- The subjecting of these tribal groups to conditions of life calculated to bring about their physical destruction, namely through cruel and inhumane treatment, including torture, physical and psychological abuse and sexual violence, deportation, and inhumane living conditions. The conditions calculated to bring about the physical destruction of these groups also included the failure to provide - or to enable the international community to provideadequate accommodation, shelter, food, water, medical care or hygienic sanitation facilities.

62. From no later than 1989 until the present, AL-BASHIR knew or had reason to know that the crimes alleged above were about to be committed or had been committed by his subordinates, and he failed to take necessary and reasonable measures to prevent such acts or punish the perpetrators thereof. He knew, or had reason to know, that his subordinates, accomplices, and coperpetrators were acting with genocidal intent.

63. Where armed militia without formal ties to governmental forces committed the crimes, the Government of Sudan at AL-BASHIR's direction and under AL-BASHIR's command and control gave substantial assistance to these militia. AL-BASHIR knew that the assistance provided by the Government of Sudan and by governmental armed forces in the form of weapons, transportation, air support, and materiel to armed militia would substantially contribute to the commission of the crimes charged above.

\section{WAR CRIMES}

64. At all times relevant to this indictment, there existed within the South and in the western region of Darfur a protracted non-international armed conflict between government forces and organized rebel groups.

65. By these acts and omissions undertaken in connection with the waging of the Second Sudanese Civil War and during the conflict in Darfur, AL-BASHIR planned, instigated, ordered, committed, or otherwise aided and abetted the planning, preparations or execution of: 
Count 9: MURDER and VIOLENCE TO LIFE AND PERSON, WAR CRIMES punishable under Article 8(2)(c)(i) of the Statute of this Tribunal.

Count 10: COMMITTING OUTRAGES UPON HUMAN DIGNITY, a WAR CRIME punishable under Article 8(2)(c)(ii) of the Statute of this Tribunal.

Count 11: INTENTIONALLY DIRECTING ATTACKS AGAINST THE CIVILIAN POPULATION, a WAR CRIME punishable under Article 8(2)(e)(II) of the Statute of this Tribunal.

Count 12: INTENTIONALLY DIRECTING ATTACKS AGAINST CIVILIAN OBJECTS, a WAR CRIME punishable under Article 8(2)(e)(iv) of the Statute of this Tribunal.

Count 13: PILLAGE, a WAR CRIME punishable under Article 8(2)(e)(v) of the Statute of this Tribunal.

Count 14: RAPE and SEXUAL VIOLENCE, WAR CRIMES punishable under Article $8(2)(e)(v i)$ of the Statute of this Tribunal.

Count 15: ORDERING THE DISPLACEMENT OF CIVILIANS, a WAR CRIME punishable under Article 8(2)(e)(viii) of the Statute of this Tribunal.

66. From no later than 1989 until the present, AL-BASHIR knew or had reason to know that the crimes alleged above were about to be committed or had been committed by his subordinates, and he failed to take necessary and reasonable measures to prevent such acts or punish the perpetrators thereof. He knew, or had reason to know, that his subordinates, accomplices, and coperpetrators were acting with genocidal intent.

67. Where armed militia without formal ties to governmental forces committed the crimes, the Government of Sudan at AL-BASHIR's direction and under AL-BASHIR's command and control gave substantial assistance to these militia. AL-BASHIR knew that the assistance provided by the Government of Sudan and by governmental armed forces in the form of weapons, transportation, air support, and materiel to armed militia would substantially contribute to the commission of the crimes charged above. 


\section{CONCLUSION}

68. By these acts and omissions, defendant President OMAR HASAN AHMAD ALBASHIR should be decreed guilty of crimes against humanity, genocide, and war crimes.

Respectfully submitted,

David Kilgour

Beth Van Schaack

Eric Ortner

Office of the Prosecutor

Dated this day the 30 of September, 2006

Sydney, Australia

Santa Clara, CA, United States of America

San Francisco, CA, United States of America 